\title{
Akty prawne (ustawa prawo ochrony środowiska oraz rozporządzenia ministra środowiska) odnoszące się do hałasu kolejowego
}

\begin{abstract}
Po przystapieniu Polski do Unii Europejskiej znacznie wzrosła aktywność w tworzeniu rozporzadzeń dotyczacych wykonywania pomiarów poziomu hatasu, w tym również dla taboru kolejowego. Obecnie ukazujq się normy, dyrektywy i rozporzqdzenia porzadkujace ta dziedzinę nauki. $W$ artykule przedstawiono wybiórczo najnowsze, obowiqzujace akty prawne dotyczace hatasu kolejowego.
\end{abstract}

\section{Wstęp}

Wejście w życie Dyrektywy 2002/49 [1] oraz przystapienie Polski do UE (05.2005r.) spowodowało nagły wzrost prac związanych $\mathrm{z}$ unormowaniem dziedziny jaka jest hałas generowany przez pojazdy szynowe Do tej pory Polska posiadała jedną główną normę odnosząca się do hałasu kolejowego PN91/K11000 [2] zatwierdzoną w 1993r. oraz Ustawę Prawo Ochrony Środowiska z 2001r [3].

Obecnie ogłaszane są nowe, dostosowane do przepisów Unii Europejskiej Rozporządzenia Ministra Środowiska regulujące $\mathrm{w}$ coraz większym stopniu tematykę związaną $\mathrm{z}$ hałasem kolejowym. W wielu przypadkach przepisy te wprowadzają dotąd nie stosowane $\mathrm{w}$ Polsce zagadnienia, jak np. sporządzanie map akustycznych.

Prawodawstwo unijne może oddziaływać na wewnętrzny porządek prawny państwa poprzez:

- Rozporządzenia - bezpośrednio zastępują regulacje krajowe przepisami Unii, mają moc wiążącą we wszystkich państwach członkowskich,

- Dyrektywy - oddziaływują pośrednio na ustawodawstwo krajowe, muszą być wprowadzone w życie w państwach członkowskich w ustawach lub innych aktach normatywnych w określonym terminie - zwykle 2 lata. Prawa i obowiązki dla obywatela państwa członkowskiego wynikają z aktów wydanych na ich podstawie przez organy danego państwa,

- Decyzje - wiążą podmioty do których są skierowane tj państwa członkowskie a także osoby fizyczne i prawne np. przedsiębiorstwo,

- Zalecenia i uchwały - nie mają mocy wiążącej są wytycznymi postępowania [17].

Wykaz literatury należy aktualizować w miarę ukazywania się nowych pozycji wydawniczych.

\section{Ustawa Prawo Ochrony Środowiska}

Konkretne zadania w zakresie eliminowania hałasu w Polsce, rozłożone na kilkanaście najbliższych lat, wynikają z ustawy - Prawo Ochrony Środowiska (27.04.2001r. w Dz. U. Nr.62 poz.627) [3], traktującej zbyt głośne dźwięki jako zanieczyszczenie środowiska i określającej takie same ogólne zasady, obowiązki i formy działania w stosunku do hałasu jak do pozostałych zanieczyszczeń.

Ustawą POŚ zostały w Polsce wdrożone regulacje dotyczące hałasu, zaproponowane początkowo w projekcie, a następnie w Dyrektywie Unii Europejskiej $w$ sprawie zarzqdzania i oceny hałasu $w$ środowisku [1].

Ustawa przewiduje m.in. obowiązek sporządzania map akustycznych i programów działań, których celem jest dostosowanie poziomu hałasu do dopuszczalnego.

Ponadto ustawa, wprowadziła bardzo istotną regulację dotycząca określania $\mathrm{w}$ miejscowym planie zagospodarowania przestrzennego standardów akustycznych środowiska.

W kolejnych latach po wydaniu POŚ wprowadzano korekty w ustawie, mające na celu udoskonalenie istniejących przepisów. I tak do tej pory ukazywały się następujące zmiany:

$\begin{array}{lll}\text { - } & \text { Dz. U. Nr.233 poz. } 1957 \text { z 2002r. } \\ \text { - } & \text { Dz. U. Nr.190 poz. } 1865 \text { z 2003r. } \\ \text { - } & \text { Dz. U. Nr.49 poz. } 464 \text { z 2004r. } \\ \text { - } & \text { Dz. U. Nr.62 poz. } 552 \text { z 2005r. } \\ \text { - } & \text { Dz. U. Nr.113 poz. } 954 \text { z 2005r. } \\ \text { - } & \text { Dz. U. Nr.21 poz. } 124 \text { z 2007r. } \\ \text { - } & \text { Dz. U. Nr.88 poz. } 587 \text { z 2007r. }\end{array}$

Ostatnie naniesione zmiany spowodowały m.in. uchylenie Rozporządzenia Ministra Środowiska z dnia 9 stycznia 2002r. w sprawie wartości progowych poziomów hałasu [4], określające wartości progowe 
poziomów hałasu w środowisku, których przekroczenie powoduje zaliczenie obszaru, na którym poziom hałasu przekracza poziom dopuszczalny, do kategorii terenu zagrożonego hałasem.

Ustawa Prawo Ochrony Środowiska wprowadza następujące akty wykonawcze związane bezpośrednio lub pośrednio $\mathrm{z}$ hałasem kolejowym:

2.1. Rozporządzenie Ministra Środowiska z dnia 14 października 2002r. w sprawie szczegółowych wymagań, jakim powinien odpowiadać program ochrony środowiska przed hałasem [5]

2.2. Rozporządzenie Ministra Środowiska $\mathrm{z}$ dnia 17 stycznia 2003r. w sprawie rodzajów wyników pomiarów prowadzonych $\mathrm{w}$ związku z eksploatacją dróg, linii kolejowych, linii tramwajowych, lotnisk oraz portów, które powinny być przekazywane właściwym organom ochrony środowiska, oraz terminów i sposobów ich prezentacji [6]

2.3. Rozporządzenie Ministra Środowiska z dnia 14 grudnia 2006r. w sprawie dróg, linii kolejowych i lotnisk, których eksploatacja może powodować negatywne oddziaływanie akustyczne na znacznych obszarach, dla których jest wymagane sporządzanie map akustycznych, oraz sposobów określania granic terenów objętych tymi mapami [7]

2.4. Obwieszczenie Ministra Środowiska $\mathrm{z}$ dnia 18 września 2007r. w sprawie wysokości stawek kar za przekroczenie warunków wprowadzania ścieków do wód lub do ziemi oraz za przekroczenie dopuszczalnego poziomu hałasu, na rok 2008 [8]

2.5. Rozporządzenie Ministra Środowiska z dnia 14 czerwca 2007r. w sprawie dopuszczalnych poziomów hałasu w środowisku [9]

2.6. Rozporządzenie Ministra Środowiska z dnia 1 października 2007r. w sprawie szczegółowego zakresu danych ujętych na mapach akustycznych oraz ich układu i sposobu prezentacji [10]

2.7. Rozporządzenie Ministra Środowiska $z$ dnia 2 października 2007r. w sprawie wymagań w zakresie prowadzenia pomiarów poziomów $\mathrm{w}$ środowisku substancji lub energii przez zarządzającego drogą, linią kolejową, linią tramwajową, lotniskiem, portem [11]

2.8. Rozporządzenie Ministra Środowiska z dnia 7 listopada 2007r. zmieniające rozporządzenie w sprawie ustalania wartości hałasu L(DWN) [12].

\section{Rozporządzenie Ministra Środowiska $z$ dnia}

7 listopada 2007r. [12] zmieniające rozporządzenie (Dz. U. Nr. 106 poz. 729 §2) [13] w sprawie ustalania wartości hałasu $\mathrm{L}_{\mathrm{DWN}}$.

Rozporządzenie określa wartość długookresowego wskaźnika hałasu $L_{D W N}$, który ustala się z zależności:
$L_{D W N}=10 \lg \left[\frac{12}{24} \cdot 10^{0,1 L_{D}}+\frac{4}{24} \cdot 10^{0,1\left(L_{W}+5\right)}+\frac{8}{24} \cdot 10^{0,1\left(L_{N}+10\right)}\right]$

gdzie:

$L_{D W N}$ - oznacza długookresowy średni poziom dźwięku A wyrażony $\mathrm{w}$ decybelach $(\mathrm{dB})$, wyznaczony $\mathrm{w}$ ciągu wszystkich dób $\mathrm{w}$ roku, $\mathrm{z}$ uwzględnieniem pory dnia (rozumianej jako przedział czasu od godz. 6.00 do godz. 18.00), pory wieczoru (rozumianej jako przedział czasu od godz. 18.00 do godz. 22.00) oraz pory nocy (rozumianej jako przedział czasu od godz. 22.00 do godz. 6.00),

$L_{D} \quad$ - oznacza długookresowy średni poziom dźwięku A wyrażony w decybelach (dB), wyznaczony w ciagu wszystkich pór dnia $\mathrm{w}$ roku (rozumianych jako przedział czasu od godz. 6.00 do godz. 18.00),

$L_{W}$ - oznacza długookresowy średni poziom dźwięku A wyrażony w decybelach (dB), wyznaczony $w$ ciagu wszystkich pór wieczoru $\mathrm{w}$ roku (rozumianych jako przedział czasu od godz.18.00 do godz. 22.00),

$L_{N}$ - oznacza długookresowy średni poziom dźwięku A wyrażony $\mathrm{w}$ decybelach (dB), wyznaczony w ciagu wszystkich pór nocy w roku (rozumianych jako przedział czasu od godz.22.00 do godz. 6.00),

Dopuszczalne wartości wskaźników hałasu określa rozporządzenie [9].

\section{Rozporządzenie Ministra Środowiska z dnia 2 października 2007r. [11]}

$Z$ dniem wejścia $w$ życie tego Rozporządzenia traci moc Rozporzqdzenie Ministra Środowiska $z$ dnia 29 stycznia 2003r. Dz. U. Nr. 35 poz. 308).

W praktyce, uchwalenie tego Rozporzadzenia nic nie zmienia $w$ polskim ustawodawstwie $w$ zakresie ochrony przed hatasem!!!

Akt prawny określa wymagania $\mathrm{w}$ zakresie prowadzenia pomiarów poziomów hałasu w środowisku, do których są obowiązani zarządzający drogą, linią kolejowa, linią tramwajowa, lotniskiem lub portem. Pomiary dotyczą hałasu emitowanego do środowiska w związku z eksploatacją tych obiektów i wykonywane są w sposób ciaggły lub okresowy. Rozporządzenie 
reguluje metodykę pomiarowa, kryteria wyboru punktów pomiarowych oraz sposób ewidencjonowania wyników.

Wyniki przeprowadzonych pomiarów hałasów ewidencjonowane są $\mathrm{w}$ formie zestawień tabelarycznych, opisów i map sytuacyjnych zapisanych w postaci drukowanej i elektronicznej.

\section{UWAGA!}

Poniżej przedstawionoważniejsze informacje dotyczqce pomiaru hatasu od linii kolejowych i tramwajowvch. Numeracja poszczególnych paragrafów oraz punktów wcelu pozostawienia spójności z tekstem oryginalnym pozostanq niezmienione.

§1. określa wymagania w zakresie prowadzenia pomiarów substancji lub energii $\mathrm{w}$ środowisku, do których są zobowiązani zarządzający drogą, linią kolejowa, linią tramwajową, lotniskiem, portem, wprowadzanych w związku z eksploatacją tych obiektów, oraz ustala przypadki, w których wymagane są: 1) ciaggłe pomiary poziomów wskazanych substancji lub energii w środowisku;

2) okresowe pomiary poziomów wskazanych substancji lub energii w środowisku;

3) referencyjne metodyki wykonywania pomiarów,

4) kryteria lokalizacji punktów pomiarowych;

5) sposoby ewidencjonowania wyników przeprowadzonych pomiarów.

§3. Okresowe pomiary poziomów substancji lub energii $\mathrm{w}$ środowisku prowadzi się dla następujących substancji lub energii:

1) hałasu w środowisku od:

c) linii kolejowych magistralnych i pierwszorzędnych - co 5 lat,

d) linii tramwajowych - co 5 lat,

§4. Referencyjne metodyki wykonywania pomiarów oraz kryteria lokalizacji punktów pomiarowych dla pomiarów:

1) okresowych - hałasu w środowisku, o których mowa $\mathrm{w}$ § 3 pkt 1 lit. a-d, są określone w załączniku nr 2 do rozporządzenia;

§5. Wyniki przeprowadzonych pomiarów poziomów substancji lub energii w środowisku wykonane w związku z eksploatacją drogi, linii kolejowej, linii tramwajowej, lotniska oraz portu są ewidencjonowane w formie zestawień tabelarycznych, opisów i map sytuacyjnych zapisanych w postaci drukowanej i elektronicznej.

Załączniki do Rozporządzenia MŚ z dnia 2 października 2007r.

\section{Załącznik nr 2}

Referencyjne metodyki wykonywania okresowych pomiarów poziomów hałasu w środowisku dla dróg, linii kolejowych, linii tramwajowych, urządzeń na terenach portów oraz kryteria lokalizacji punktów pomiarowych

\section{POSTANOWIENIA OGÓLNE}

\section{Stosowane metody}

Okresowe pomiary poziomów hałasu w środowisku, powodowanego ruchem drogowym, kolejowym, tramwajowym i urządzeń związanych z pracą portu, wykonuje się, wykorzystując:

a) metodę pośrednią, to jest metodę pomiarów pojedynczych zdarzeń akustycznych,

b) metodę bezpośrednich pomiarów hałasu $\mathrm{z}$ wykorzystaniem próbkowania,

c) metodę bezpośrednią ciagłych pomiarów $\mathrm{w}$ ograniczonym czasie,

d) metody obliczeniowe oparte o modele rozprzestrzeniania się dźwięku w środowisku.

Metoda pomiarów pojedynczych zdarzeń akustycznych stosowana jest $\mathrm{w}$ pomiarach hałasu:

a) dla linii kolejowych i tramwajowych, Metoda bezpośrednich pomiarów hałasu $\mathrm{z}$ wykorzystaniem próbkowania stosowana jest głównie do pomiaru hałasu dla dróg o natężeniu ruchu przekraczającym 300 pojazdów na godzinę.

Metoda bezpośrednia ciagłych pomiarów w ograniczonym czasie stosowana jest do nieprzerwanych wielogodzinnych lub wielodniowych obserwacji hałasu w danym punkcie pomiarowym.

Metody obliczeniowe mogą być stosowane w odniesieniu do wszystkich wymienionych wyżej źródeł hałasu.

Powyższe metody służą do wyznaczenia wartości równoważnego poziomu hałasu wraz z niepewnością oszacowania:

$$
L_{A e q, T} \pm \Delta L_{A e q, T} \text { w decybelach }[\mathrm{dB}]
$$

gdzie:

$L_{A e q, T}$ - uzyskana w wyniku pomiarów wartość równoważnego poziomu dźwięku dla czasu odniesienia $T[\mathrm{~dB}]$,

$\Delta L_{\text {Aeq,T }}$ - niepewność oszacowania wartości poziomu równoważnego $[\mathrm{dB}]$.

\section{!!! Rozporządzenie nie określa metod wyznaczania wartości niepewności $\Delta L_{A e q, T} ! ! !^{1}$}

\footnotetext{
${ }^{1}$ zasady prawidłowego określania niepewności pomiarów akustycznych przedstawiono w punkcie 11 tego artykułu.
} 
2. Ogólne wymagania dotyczące zestawów pomiarowych

Zestawy pomiarowe powinny być tak dobrane, by można było za ich pomoca wyznaczyć równoważny poziom dźwięku A zarówno metodami bezpośrednimi, jak pośrednimi, to znaczy przez pomiary ekspozycyjnych poziomów dźwięku.

Do bezpośrednich ciąłych pomiarów w ograniczonym czasie mogą być stosowane zestawy przyrządów pomiarowych wykonujących automatyczne pomiary hałasu oraz warunków meteorologicznych.

Zestawy przyrządów pomiarowych, to jest mierników poziomu dźwięku wraz $\mathrm{z}$ mikrofonem oraz innych przyrządów używanych do pomiarów poziomów dźwięku, powinny mieć 1 klasę dokładności.

Wzorcowe źródła dźwięku używane do wzorcowania toru pomiarowego muszą mieć klasę dokładności minimum 1 .

Mikrofony pomiarowe powinny mieć założone osłony przeciwwietrzne, niezależnie od warunków atmosferycznych.

\section{Wzorcowanie, legalizacja}

Pomiary moga być wykonywane wyłącznie za pomocą przyrządów z ważnym świadectwem legalizacji.

Wszystkie przyrządy używane do pomiarów hałasu powinny być wzorcowane, a sposób wzorcowania musi być zgodny z instrukcją dostarczaną przez producenta przyrządu.

\section{Warunki meteorologiczne}

Pomiary hałasu wykonuje się w warunkach meteorologicznych, zapewniających najbardziej stabilne warunki w czasie rozprzestrzeniania się dźwięku z dodatnią składową prędkości wiatru od źródła do punktu pomiarowego, takich jak:

a) prędkość wiatru $0-5 \mathrm{~m} / \mathrm{s}$ określona na wysokości położenia najwyższego punktu obserwacji,

b) brak silnej inwersji temperaturowej przy gruncie,

c) temperatura powyżej $-5^{\circ} \mathrm{C}$,

d) brak opadów atmosferycznych.

Stosując metodę bezpośrednich, ciagłych pomiarów w ograniczonym czasie pomiary parametrów meteorologicznych wykonuje się równocześnie z pomiarami hałasu.

\section{OGÓLNE ZASADY LOKALIZACJI PUNKTÓW POMIAROWYCH DLA PO- MIARÓW OKRESOWYCH}

\section{Informacje wstępne}

Lokalizacja punktów pomiarowych ustalana jest indywidualnie dla każdego pomiaru w zależności od aktualnego celu pomiarów, charakterystyk źródła hałasu oraz rodzaju pokrycia i zagospodarowania obszaru, na którym wykonywane są pomiary. tegorie: a) referencyjne,

b) pozostałe.

Referencyjne punkty pomiarowe służą do oceny i monitorowania zmienności parametrów akustycznych źródła hałasu. Uzyskane w nich wyniki służą za punkt odniesienia do:

a) oceny akustycznej źródła,

b) interpretacji wyników pomiarów uzyskanych w pozostałych punktach pomiarowych.

\section{Kryteria lokalizacji referencyjnych punktów} pomiarowych

Referencyjny punkt pomiarowy lokalizuje się na wysokości 4,0 $\mathrm{m} \pm 0,1 \mathrm{~m}$. Jeżeli w miejscu lokalizacji punktu referencyjnego znajdują się przeszkody na drodze rozprzestrzeniania się dźwięku (takie jak mur, płot, budynek), punkt sytuuje się na wysokości minimum $0,5 \mathrm{~m}$ nad tą przeszkodą.

W przypadkach pomiarów hałasu w miejscu projektowanego ekranu akustycznego, punkt referencyjny pomiarów sytuuje się $\mathrm{W}$ płaszczyźnie ekranu na wysokości minimum $0,5 \mathrm{~m}$ ponad przewidywaną górną krawędzią ekranu.

Dla linii kolejowych poza miastem, niezabudowanych, punkt referencyjny w miarę możliwości oddala się do $25 \mathrm{~m}$.

Przyjmuje się zasadę, iż pomiar w jednym punkcie referencyjnym charakteryzuje emisję hałasu $\mathrm{z}$ danego jednorodnego pod względem akustycznym odcinka drogi lub linii kolejowej, przy czym ta jednorodność dotyczy nie tylko parametrów ruchu i arterii (linii kolejowej), lecz jednocześnie najbliższego otoczenia.

Jeżeli arteria (drogowa, szynowa) biegnie po nasypie, estakadzie itp., a warunki na to pozwalaja, referencyjny punkt pomiarowy hałasu lokalizuje się także zgodnie $\mathrm{z}$ wymienionymi zasadami, przy czym wysokość punktu pomiarowego liczona jest w stosunku do wysokości jezdni (nawierzchni torowej).

Dla dróg przebiegających w wykopie referencyjny punkt pomiarowy lokalizuje się w odległości $1 \mathrm{~m}$ od krawędzi wykopu na wysokości $4,0 \mathrm{~m} \pm 0,1 \mathrm{~m}$.

\section{Kryteria lokalizacji pozostałych punktów pomiarowych hałasu w środowisku}

W przypadku pomiarów hałasu na terenie chronionym, nie przeznaczonym pod zabudowę, punkt pomiarowy lokalizuje się na wysokości 1,5 $\mathrm{m}$ nad powierzchnią terenu.

W przypadkach skomplikowanego ukształtowania lub zagospodarowania terenu (takiego jak teren pagórkowaty) lokalizacja punktów pomiarowych musi być rozpatrywana indywidualnie.

Jeżeli pomiary hałasu prowadzone są na terenie zabudowanym, to $\mathrm{w}$ celu zminimalizowania 
wpływu odbić dźwięku, punkty pomiarowe powinny być sytuowane w odległości co najmniej 3,5 m od najbliższej płaszczyzny odbijającej (poza podłożem).

Jeżeli pomiary hałasu odnoszą się do terenu, na którym usytuowana jest zabudowa wymagająca ochrony akustycznej, to punkt pomiarowy hałasu w środowisku lokalizuje się w odległości od 1 do $2 \mathrm{~m}$ od ściany zewnętrznej oraz na wysokości 1,5 $\mathrm{m}$ nad poziomem podłogi kondygnacji, na której poziom hałasu jest najwyższy.

Kondygnację, na której poziom hałasu jest najwyższy, ustala się, poprzedzając właściwy pomiar hałasu pomiarami orientacyjnymi na poszczególnych kondygnacjach.

W przypadku pomiarów hałasu na obszarach przeznaczonych pod zabudowę punkt pomiarowy sytuowany jest na granicy przewidywanej zabudowy na wysokości:

a) $4 \mathrm{~m}$ nad poziomem terenu $\mathrm{w}$ przypadku przewidywanej zabudowy jednorodzinnej,

b) $10 \mathrm{~m}$ nad poziomem terenu $\mathrm{w}$ przypadku przewidywanej zabudowy wielorodzinnej.

III. METODA POŚREDNIA - METODA POMIARÓW POJEDYNCZYCH ZDARZEŃ AKUSTYCZNYCH

a) terenowych pomiarach ekspozycyjnych poziomów dźwięku,

b) wyznaczeniu równoważnego poziomu dźwięku na podstawie zmierzonych poziomów ekspozycyjnych.

Ekspozycyjne poziomy dźwięku, oznaczane $\mathrm{L}_{\mathrm{AE}}$, mierzone są dla pojedynczych zdarzeń akustycznych.

Pojedyncze zdarzenia akustyczne łączy się w klasy. Dla każdej klasy wyznaczana jest wartość średnia oraz odchylenie standardowe.

Podstawowym kryterium łączenia pojedynczych zdarzeń akustycznych w klasy jest uzyskanie możliwie niskiej wartości odchylenia standardowego dla klasy, oznaczonego jako $\sigma L_{A E}$.

W pomiarach hałasu dla linii kolejowych określa się 3 klasy pojedynczych zdarzeń akustycznych, polegających na przejeździe przed punktem pomiarowym:

a) pociągu pasażerskiego dalekobieżnego (takiego jak pospieszny, EuroCity, InterCity),

b) pociagu pasażerskiego lokalnego,

c) pociagu towarowego.

Czas pomiaru poziomu $L_{A E}$ dla każdego pojedynczego zdarzenia akustycznego nie może być mniejszy niż akustyczny czas trwania zjawiska, to znaczy by wartość chwilowa poziomu dźwięku generowanego przez wydarzenie akustyczne zawierała się $\mathrm{w}$ przedziale:

$$
\text { gdzie: } L_{A \max }-10 d B \leq L_{A}(t) \leq L_{A \max }
$$

$L_{A}(t)$ - chwilowa wartość poziomu dźwięku, $\mathrm{dB}$,

$L_{A \max } \quad$ - maksymalna wartość poziomu dźwięku.

Dla każdej klasy pojedynczych zdarzeń akustycznych oblicza się średnią wartość poziomu ekspozycyjnego według wzoru:

$$
L_{A E k}=10 \lg \left[\frac{1}{n} \sum_{i=1}^{n} 10^{0.1 L_{A E k i}}\right]
$$

w którym:

$\mathrm{n}$ - liczebność klasy, to jest liczba pomiarów pojedynczych zdarzeń akustycznych k-tej klasy,

$L_{A E k}$ - średni dla k-tej klasy poziom ekspozycyjny $\mathrm{w} \mathrm{dB}$,

$L_{A E k i}{ }^{-}$zmierzona wartość poziomu ekspozycyjnego zakwalifikowanego do k-tej klasy.

Dla każdej klasy pojedynczych zdarzeń akustycznych określa się odchylenie standardowe $\mathrm{w}$ próbce według wzoru:

$$
\sigma_{L_{A E k}}=\sqrt{\frac{1}{n-1} \sum_{i=1}^{n}\left(L_{A E k i}-L_{A E k}\right)^{2}}
$$

oznaczenia jak poprzednio ${ }^{2}$

Wynikową wartość równoważnego poziomu dźwięku określa się z zależności:

$$
L_{\text {Aeq }}=10 \lg \left[\frac{1}{T} \sum_{k=1}^{m} N_{k} 10^{0.1 L_{A E k}}\right]
$$

gdzie:

$\mathrm{T}$ - czas odniesienia w sekundach,

$N_{k}$ - iczba pojedynczych zdarzeń akustycznych k-tej klasy zaobserwowana $\mathrm{w}$ czasie odniesienia $\mathrm{T}$,

$L_{A E k}$ - średni dla k-tej klasy poziom ekspozycyjny $\mathrm{w} \mathrm{dB}$,

$\mathrm{m}$ - liczba klas pojedynczych zdarzeń akustycznych.

\section{METODA BEZPOŚREDNIA CIĄGLYCH POMIARÓW W OGRANICZONYM CZA- SIE}

Przy zastosowaniu tej metody wartości równoważnego poziomu dźwięku dla badanego hałasu wyznacza się w oparciu o wyniki ciaggłej obserwacji zmian poziomu w czasie odniesienia.

\footnotetext{
${ }^{1}$ wzór jest nieprawidłowy z fizycznego punktu widzenia patrz punkt 11 artykułu - przyp.MK
} 
Z pełnego okresu ciagłego pomiaru hałasu eliminuje się dane uzyskane w odcinkach czasu, w których warunki atmosferyczne nie odpowiadają warunkom podanym $\mathrm{w}$ I.4.

Dla odcinków czasu, dla których wyeliminowano wyniki obserwacji poziomów dźwięku, ich wartości wyznacza się w oparciu o metody obliczeniowe.

\section{METODY OBLICZENIOWE}

Metody obliczeniowe hałasu od dróg, linii kolejowych, linii tramwajowych, urządzeń i statków w porcie oparte powinny być o model rozprzestrzeniania się dźwięku w środowisku, zawarty w normie PN ISO 9613-2 [14].

Zastosowanie modelu obliczeniowego może wymagać pomiarów w celu ustalenia wielkości wejściowych do obliczeń dotyczących emisji hałasu ze źródeł. Pomiary takie przeprowadza się w oparciu o metody podane $\mathrm{W}$ III-V.

\section{DANE REJESTROWANE W PROTO- KOLACH I SPRAWOZDANIACH Z BA- DAŃ}

Każdy pomiar musi być udokumentowany protokołem pomiarowym zawierającym:

1. Zastosowana metoda pomiarów:

Nazwa lub krótki opis (charakterystyka metody).

2. Przyrządy pomiarowe i wyposażenie:

1) użyte przyrządy pomiarowe, nazwy i typy poszczególnych przyrządów,

2) metody stosowane do okresowych kontroli mikrofonów i elementów składowych systemów pomiarowych (nr świadectwa legalizacji),

3) ustawienia przyrządów pomiarowych (charakterystyka korekcyjna A, zastosowana stała czasowa).

3. Charakterystyka terenu, na którym prowadzono pomiary halasu.

Opis terenu, na którym prowadzono badania, a w tym szkice lub fotografie pokazujące:

1) ukształtowanie terenu,

2) powierzchnię terenu,

3) zabudowę,

4) obiekty odbijające fale akustyczne w otoczeniu źródła i punktu pomiarowego,

5) klasyfikację terenu z punktu widzenia planu zagospodarowania przestrzennego,

6) dopuszczalne poziomy hałasu.

4. Charakterystyka lokalizacji punktu pomiarowego:

1) odległość punktu pomiarowego od źródła,

2) wysokość punktu pomiarowego,
3) współrzędne geograficzne i/lub topograficzne punktu pomiarowego.

\section{Charakterystyka źródła halasu.}

Dane niezbędne do identyfikacji źródła i interpretacji wyników. Charakterystyki te są różne w zależności od mierzonego źródła:

Hałas dla linii kolejowych i tramwajowych:

1) nazwa odcinka linii, przy której prowadzone są pomiary hałasu,

2) rodzaj linii:

a) miejska,

b) pozamiejska,

3) parametry linii:
a) długość odcinka, przy którym prowadzone są badania,
b) liczba torów,
c) trakcja,
d) niweleta trasy,
e) stan torowiska (opisowo),

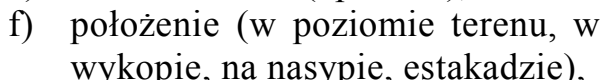

4) parametry ruchu:
a) liczba pociagów danego typu,
b) średnia prędkość danego typu po- ciagu,
c) średnia długość pociagu danego typu,

5) otoczenie źródła hałasu:
a) rodzaj zabudowy:
- po stronie wykonywania po- miarów,
- po przeciwnej stronie,

b) odległość pierwszej linii zabudowy od linii:

- po stronie wykonywania pomiarów,

- po przeciwnej stronie,

c) wysokość pierwszej linii zabudowy:

- po stronie wykonywania pomiarów,

- po przeciwnej stronie,

d) liczba obiektów (budynków) bezpośrednio eksponowanych na hałas:

- po stronie wykonywania pomiarów,

- po przeciwnej stronie,

e) oszacowana liczba mieszkańców (osób) eksponowanych na hałas.

\section{Warunki meteorologiczne:}

1) prędkość i kierunek wiatru,

2) względna wilgotność,

3) temperatura,

4) ciśnienie.

7. Wyniki pomiarów - dane akustyczne:

1) pora doby, której dotyczą pomiary, 
1) wyniki wszystkich badań (pomiarów) w punktach obserwacji i punkcie odniesienia (referencyjnym),

2) wartość poziomu równoważnego wraz z niepewnością, w każdym punkcie pomiarowym,

3) przekroczenia dopuszczalnych poziomów hałasu,

4) nazwa $i$ adres instytucji wykonującej badania, data badań,

6) osoba odpowiedzialna za przeprowadzenie badań.

8. Załączniki graficzne - szkic poligonu badań:

1) wycinek planu z zaznaczeniem położenia źródła, punktów obserwacji, innych pobliskich obiektów o charakterze ekranującym lub powodujących odbicia,

2) szkice przybliżające lokalizację i wzajemne usytuowanie punktów obserwacji, źródła, punktów odniesienia (referencyjnych), pobliskich obiektów mających wpływ na pole akustyczne, z uwzględnieniem przekrojów pozioObjaśnienie: mych i pionowych (wysokości).

Użyte w niniejszym załączniku określenia są zgodne z normami PN ISO-1996-1/2 [15] .

\section{Rozporządzenie Ministra Środowiska z dnia}

1 października 2007r. [10]

Rozporządzenie implementuje przepisy Dyrektywy 2002/49/WE [1] Parlamentu Europejskiego i Rady z dnia 25 czerwca 2002 r. w sprawie oceny i zarządzania poziomem hałasu $\mathrm{w}$ środowisku. Zgodnie $\mathrm{z}$ zapisami ww. dyrektywy (art. 1) kraje członkowskie zobowiązane są do:

- określenia stopnia narażenia na hałas w środowisku poprzez sporządzenie map akustycznych;

- zapewnienia społeczeństwu dostępu do informacji na temat hałasu $\mathrm{w}$ środowisku $\mathrm{i}$ jego skutków;

- $\quad$ przyjęcia, w oparciu o dane pochodzące z map akustycznych, planów działań zmierzających do zapobiegania powstawaniu hałasu w środowisku i obniżania jego poziomu, szczególnie w sytuacji zagrożenia zdrowia ludzi.

Mapy akustyczne są elementem długookresowej polityki ochrony środowiska przed hałasem. Ocena stanu akustycznego środowiska, obejmująca między innymi wykonanie map akustycznych, jest obligatoryjna w ramach Państwowego Monitoringu Środowiska (PMŚ).

Nowe Rozporządzenie Ministra Środowiska określa szczegółowy zakres danych, które powinny być ujęte na mapach akustycznych oraz ich układ i sposób prezentacji w celu ich wykorzystywania do opracowania danych dla PMŚ.

Mapy akustyczne składają się z części opisowej, zawierającej informacje wprowadzające, tabelaryczne zestawienia wyników, wykresy, dokumentację fotograficzną i wnioski, oraz części graficznej złożonej z szeregu map tematycznych obrazujących stan klimatu akustycznego.

W części opisowej bardzo ważny element stanowi charakterystyka obszaru podlegającego ocenie, w tym ogólny opis terenu objętego mapa $\mathrm{z}$ podstawowymi danymi statystycznymi, identyfikacja i charakterystyka źródeł hałasu, uwarunkowania akustyczne wynikające z miejscowego planu zagospodarowania przestrzennego lub innych dokumentów prawa miejscowego (np. Studium uwarunkowań i kierunków zagospodarowania przestrzennego gminy) i dokumentów planistycznych (np. opracowanie ekofizjograficzne).

Zakres danych części opisowej mapy akustycznej jest zróżnicowany w zależności od obszaru objętego mapa, ponieważ rozróżnia się mapy akustyczne dla obszaru aglomeracji oraz mapy akustyczne dla obszarów położnych w otoczeniu dróg, linii kolejowych oraz portów lotniczych.

Zakres danych części graficznej obejmuje mapy opracowane osobno dla każdego rozpatrywanego rodzaju źródła hałasu oraz osobno dla stosowanych wskaźników oceny ( $\left.\mathrm{L}_{\mathrm{DWN}} \mathrm{i} \mathrm{L}_{\mathrm{N}}\right)$, w szczególności:

- Mapę emisyjną (charakteryzującą hałas emitowany z poszczególnych źródeł);

- Mapę imisyjną (mapę stanu akustycznego środowiska kształtowanego przez dany rodzaj źródła hałasu np. kolejowego);

- Mapę wrażliwości hałasowej obszarów (w zależności od sposobu zagospodarowania terenu i jego funkcji);

- Mapę terenów zagrożonych hałasem, obrazująca przekroczenia dopuszczalnych poziomów dźwięku;

- Mapę pokazującą liczbę osób eksponowanych na hałas.

Mapy akustyczne stanowią podstawę do tworzenia $\mathrm{i}$ aktualizacji programów ochrony środowiska przed hałasem. Tereny objete programami ochrony przed hatasem to miedzy innymi tereny polożone w zasiegu oddzialywania akustycznego glównych dróg, linii kolejowych i lotnisk.

\section{Rozporządzenie Ministra Środowiska z dnia 14 czerwca 2007r. w sprawie dopuszczalnych po- ziomów hałasu w środowisku [9].}

$Z$ dniem wejścia $w$ życie niniejszego Rozporzqdzenia traci moc Rozporzqdzenie Ministra Środowiska z dnia 29 lipca 2004r. Dz. U. Nr. 178 poz. 1841).

W Rozporządzeniu pozostawiono dotychczasowe wartości dopuszczalne dla celów kontrolnych (dla 
dróg, kolei i przemysłu). Istotną zmianą jest wprowadzenie przypisu dotyczącego pory nocnej dla "terenów zabudowy zwiqzanej ze statym lub czasowym pobytem dzieci i młodzieży" oraz wykreślenie słowa "poza miastem" przy "terenach rekreacyjnowypoczynkowych" - konsekwencją tego może być objęcie ochroną np. ogródków działkowych, które kiedyś były w dawnej strefie ochronnej zakładu przemysłowego. Dodano również przypis dotyczący pory nocnej dla "terenów rekreacyjno-wypoczynkowych".

Usunięto kategorię "tereny zabudowy mieszkaniowej jednorodzinnej z ustugami rzemieślniczymi", za to wprowadzono jednoznacznie określoną kategorię "tereny mieszkaniowo-ushugowe".

Wprowadza się takie same wartości długookresowych wskaźników $L_{D W N}$ i $L_{N}$ jak wskaźniki $L_{A e q D}$ i $L_{A e q N}$ - czego konsekwencja jest Zaostrzenie polityki długookresowej w stosunku do dróg, kolei i przemysłu, jako że wskaźnik $L_{D W N}$ zawiera w sobie ostrzejszy o $5 \mathrm{~dB}$ poziom wieczorny oraz o $10 \mathrm{~dB}$ poziom nocny!

Natomiast pozostawiając dla pewnych kategorii terenów różnice pomiędzy $L_{D W N}$ i $L_{N} \mathrm{w}$ wysokości $5 \mathrm{~dB}$ powoduje się to, że w większości przypadków dla tych terenów wartość wskaźnika nocnego będzie bezprzedmiotowa, bo we wskaźniku $L_{D W N}$ poziom nocny jest o $10 \mathrm{~dB}$ ostrzejszy.

Poza tym Rozporządzenie ma zastosowanie, w przypadku ustalania wykazu miejscowości, w których może być pobierana opłata miejscowa (pobierana za każdy dzień pobytu od osób fizycznych przebywających dłużej niż dobę w celach turystycznych, wypoczynkowych lub szkoleniowych). Miejscowość ubiegająca się o taki status powinna spełniać minimalne warunki klimatyczne tzn. zachowanie w miejscowości dopuszczalnych poziomów hałasu, określonych w niniejszym rozporządzeniu Ministra Środowiska.

\section{$\begin{array}{llll}\text { ZALACZNIK } & & \\ \text { DOPUSZCZALNE POZIOMY HALASU W }\end{array}$ \\ DOLACZNIK ŚRODOWISKU}

Dopuszczalne poziomy halasu $w$ środowisku powodowanego przez poszczególne grupy źródel halasu (*) w odniesieniu do jednej doby

Tabela 1

\begin{tabular}{|c|c|c|c|c|}
\hline \multirow{4}{*}{$L p}$. & \multirow{4}{*}{\multicolumn{2}{|c|}{ Rodzaj terenu }} & \multirow{2}{*}{\multicolumn{2}{|c|}{$\begin{array}{c}\text { Dopuszczalny poziom hatasu w [dB] } \\
\text { Drogi lub linie kolejowe }^{l)}\end{array}$}} \\
\hline & & & & \\
\hline & & & $L_{A e q D}$ & $L_{A e q N}$ \\
\hline & & & $\begin{array}{c}\text { przedział czasu } \\
\text { odniesienia równy } \\
16 \text { godzinom }\end{array}$ & $\begin{array}{c}\text { przedział czasu odnie- } \\
\text { sienia równy } \\
8 \text { godzinom }\end{array}$ \\
\hline 1 & & $\begin{array}{l}\text { Strefa ochronna „A” uzdrowiska } \\
\text { Tereny szpitali poza miastem }\end{array}$ & 50 & 45 \\
\hline 2 & $\begin{array}{l}\text { a) } \\
\text { b) }\end{array}$ & $\begin{array}{l}\text { Tereny zabudowy mieszkaniowej } \\
\quad \text { jednorodzinnej } \\
\text { Tereny zabudowy związanej ze sta- } \\
\text { łym lub czasowym pobytem dzieci i } \\
\text { młodzieży }{ }^{2)} \\
\text { Tereny domów opieki społecznej } \\
\text { Tereny szpitali w miastach }\end{array}$ & 55 & 50 \\
\hline 3 & $\begin{array}{l}\text { b) } \\
\text { c) }\end{array}$ & $\begin{array}{l}\text { Tereny zabudowy mieszkaniowej } \\
\text { wielorodzinnej } \\
\text { i zamieszkania zbiorowego } \\
\text { Tereny zabudowy zagrodowej } \\
\text { Tereny rekreacyjno - wypoczynkowe } \\
\text { 2) } \\
\text { Tereny mieszkaniowo - usługowe }\end{array}$ & 60 & 50 \\
\hline 4 & & $\begin{array}{l}\text { eny w strefie śródmiejskiej miast powy- } \\
100 \text { tys. mieszkańców } 3 \text { - }\end{array}$ & 65 & 55 \\
\hline
\end{tabular}

* z wytaczeniem hałasu powodowanego przez starty, ladowania i przeloty statków powietrznych oraz linie elektroenergetyczne, wyrażone wskaźnikami $L_{A e q D} i L_{\text {AeqN }}$, które to wskaźniki majq zastosowanie do ustalania i kontroli warunków korzystania ze środowiska

Objaśnienia:

1) Wartości określone dla dróg i linii kolejowych stosuje się także dla torowisk tramwajowych poza pasem drogowym i kolei linowych.

2) W przypadku niewykorzystania tych terenów, zgodnie $\mathrm{z}$ ich funkcją, w porze nocy, nie obowiązuje na nich dopuszczalny poziom hałasu w porze nocy

3) Strefa śródmiejska miast powyżej 100tys. mieszkańców to teren zwartej zabudowy mieszkaniowej z koncentracją obiektów administracyjnych, handlowych i usługowych. W przypadku miast, w których występują dzielnice o liczbie mieszkańców pow. 100 tys., można wyznaczyć w tych dzielnicach strefę śródmiejska, jeżeli charakteryzuje się ona zwartą zabudową mieszkaniową z koncentracją obiektów administracyjnych, handlowych i usługowych. 
Dopuszczalne poziomy hałasu w środowisku powodowanego przez poszczególne grupy źródel hałasu ( *) dla wszystkich dób w roku

Tabela 2

\begin{tabular}{|c|c|c|c|c|}
\hline \multirow[b]{2}{*}{$L p}$. & \multirow{2}{*}{\multicolumn{2}{|c|}{ Rodzaj terenu }} & \multicolumn{2}{|c|}{ 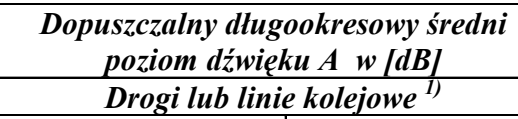 } \\
\hline & & & $\begin{array}{l}L_{D W N} \\
\text { przedział czasu } \\
\text { odniesienia równy } \\
\text { wszystkim dobom w } \\
\text { roku }\end{array}$ & $\begin{array}{l}\qquad L_{N} \\
\text { przedział czasu } \\
\text { odniesienia równy } \\
\text { wszystkim porom } \\
\text { nocy }\end{array}$ \\
\hline 1 & & $\begin{array}{l}\text { Strefa ochronna „A” uzdrowiska } \\
\text { Tereny szpitali poza miastem }\end{array}$ & 50 & 45 \\
\hline 2 & & $\begin{array}{l}\text { Tereny zabudowy mieszkaniowej jednorodzinnej } \\
\text { Tereny zabudowy związanej ze stałym lub czasowym poby- } \\
\text { tem dzieci i młodzieży } \\
\text { Tereny domów opieki społecznej } \\
\text { Tereny szpitali w miastach }\end{array}$ & 55 & 50 \\
\hline 3 & & $\begin{array}{l}\text { Tereny zabudowy mieszkaniowej wielorodzinnej } \\
\text { i zamieszkania zbiorowego } \\
\text { Tereny zabudowy zagrodowej } \\
\text { Tereny rekreacyjno - wypoczynkowe } \\
\text { Tereny mieszkaniowo - usługowe }\end{array}$ & 60 & 50 \\
\hline 4 & & 2) w strefie śródmiejskiej miast powyżej 100 tys. mieszkań- & 65 & 55 \\
\hline
\end{tabular}

* z wytaczeniem hałasu powodowanego przez starty, lqdowania i przeloty statków powietrznych oraz linie elektroenergetyczne, wyrażone wskaźnikami $L_{D W N} i L_{N}$, które to wskaźniki maja zastosowanie do prowadzenia dtugookresowej polityki w zakresie ochrony przed hałasem

Objaśnienia:

Wartości określone dla dróg i linii kolejowych stosuje się także dla torowisk tramwajowych poza pasem drogowym i kolei linowych.

Strefa śródmiejska miast powyżej 100tys. mieszkańców to teren zwartej zabudowy mieszkaniowej z koncentracją obiektów administracyjnych, handlowych i usługowych. W przypadku miast, w których występują dzielnice o liczbie mieszkańców pow. 100 tys., można wyznaczyć w tych dzielnicach strefę śródmiejską, jeżeli charakteryzuje się ona zwartą zabudową mieszkaniową z koncentracją obiektów administracyjnych, handlowych i usługowych.

7. Obwieszczenie Ministra Środowiska $\mathrm{z}$ dnia $\mathbf{1 8}$ września 2007r. - załącznik 5 [8]

Określa, wysokości kar za przekroczenie warunków wprowadzenia ścieków do wód lub ziemi oraz za przekroczenie dopuszczalnego poziomu halasu, na rok 2008. (Dane należy aktualizować corocznie).

Tabela 3 Wysokość kar za przekroczenie dopuszczalnego poziomu halasu

\begin{tabular}{|c|c|c|}
\hline \multirow{2}{*}{ Wielkość przekroczenia } & \multicolumn{2}{|c|}{$\begin{array}{c}\text { w zl za każdy dB } \\
\text { przekroczenia }\end{array}$} \\
\cline { 2 - 3 } & $\begin{array}{c}\text { w porze } \\
\text { dnia }\end{array}$ & $\begin{array}{c}\text { w porze } \\
\text { nocy }\end{array}$ \\
\hline od 1 do 5 dB & 9,19 & 11,50 \\
\hline powyżej 5 do $10 \mathrm{~dB}$ & 16,10 & 19,55 \\
\hline powyżej 10 do $15 \mathrm{~dB}$ & 23,00 & 27,61 \\
\hline powyżej $15 \mathrm{~dB}$ & 34,49 & 41,41 \\
\hline
\end{tabular}

UWAGA: nie dotyczy dróg, linii tramwajowych ani linii kolejowych!
8. Rozporządzenie Ministra Środowiska $z$ dnia 14.12.2006r. [7] w sprawie dróg, linii kolejowych i lotnisk kolejowych i lotnisk, których eksploatacja może powodować negatywne oddziaływanie akustyczne na znacznych obszarach, dla których jest wymagane sporządzanie map akustycznych, oraz sposobów określania granic terenów objętych tymi mapami.

\section{$\underline{U W A G A !}$}

Poniższy tekst zawiera wylqcznie informacje dotyczace pomiaru hatasu od linii kolejowych i tramwajowych. Numeracja poszczególnych paragrafów oraz punktów w celu pozostawienia spójności z tekstem oryginalnym pozostanq niezmienione. 
§ 1. Rozporządzenie określa:

1) drogi, linie kolejowe i lotniska, których eksploatacja może powodować negatywne oddziaływanie akustyczne na znacznych obszarach, dla których jest wymagane sporządzanie map akustycznych;

2) terminy zaliczenia dróg, linii kolejowych i lotnisk do obiektów, których eksploatacja może powodować negatywne oddziaływanie na środowisko;

3) sposoby określania granic terenów objętych mapami, o których mowa w pkt 1.

§ 2. Do obiektów, których eksploatacja może powodować negatywne oddziaływanie akustyczne na znacznych obszarach, zalicza się:

1) z dniem wejścia $w$ życie rozporządzenia:

a) linie kolejowe, po których przejeżdża ponad $\mathbf{6 0}$ 000 pociagów rocznie,

2) z dniem 1 stycznia 2011 r.:

a) linie kolejowe, po których przejeżdża ponad 30 000 pociagów rocznie.

§ 3. Granice terenów objętych mapą akustyczną, w związku z eksploatacją dróg, linii kolejowych oraz lotnisk, o których mowa $\mathrm{w} \S 2$, określa się liniami rozgraniczającymi, pokrywającymi się z izoliniami odpowiadającymi wartościom długookresowego średniego poziomu dźwięku A, wyrażonego $\mathrm{w}$ decybelach $(\mathrm{dB})$ :

1) wyznaczonego w ciagu wszystkich dób w ro$\mathrm{ku}-\boldsymbol{L}_{\boldsymbol{D W N}}=\mathbf{5 5}$;

2) wyznaczonego w ciagu wszystkich pór nocy $\mathrm{w}$ roku $-\boldsymbol{L}_{N}=\mathbf{5 0}$.

9. Rozporządzenie Ministra Środowiska $z$ dnia 17.01.2003r. [6] w sprawie rodzajów wyników pomiarów prowadzonych w związku z eksploatacja dróg, linii kolejowych, linii tramwajowych, lotnisk oraz portów, które powinny być przekazywane właściwym organom ochrony środowiska, oraz terminów i sposobów ich prezentacji

UWAGA!

Poniższy tekst zawieral będzie wytacznie informacje dotyczqce pomiaru hatasu od linii kolejowych i tramwajowych. Numeracja poszczególnych paragrafów oraz punktów w celu pozostawienia spójności z tekstem oryginalnym pozostanq niezmienione.
§1. Rozporządzenie określa rodzaje wyników pomiarów prowadzonych w związku z eksploatacja dróg, linii kolejowych, linii tramwajowych, lotnisk oraz portów, które ze względu na szczególne znaczenie dla systematycznej obserwacji zmian stanu środowiska, wynikających z eksploatacji tych obiektów, powinny być przekazywane właściwym organom ochrony środowiska, oraz terminy i sposób ich prezentacji.

§ 2. Właściwemu organowi ochrony środowiska przedkłada się wyniki:

2) okresowych pomiarów poziomów substancji lub energii w środowisku na skutek eksploatacji:

a ) dróg, linii kolejowych, linii tramwajowych, na które, na mocy art. 176 ustawy z dnia 27 kwietnia 2001 r. - Prawo ochrony środowiska oraz $w$ związku $\mathrm{z}$ art. 175 ust. 1 i ust. 3 tej ustawy, został nałożony obowiązek ich prowadzenia.

§3. Wyniki ciągłych i okresowych pomiarów emisji substancji lub energii wprowadzanej do środowiska, o których mowa $\mathrm{w} \S 2$, przedkłada się w formie drukowanych zestawień tabelarycznych, opisów, szkiców i schematów sytuacyjnych..

$\S 4$.

3) Układ przekazywanych wyników okresowych pomiarów poziomów hałasu w środowisku dla linii kolejowych i tramwajowych jest określony w załączniku nr 3 do rozporządzenia.

$\S 6$.

1) Wyniki ciągłych pomiarów hałasu $\mathrm{w}$ środowisku, prowadzone w okresie miesiąca kalendarzowego, przekazuje się w terminie 30 dni od dnia zakończenia pomiarów.

2) Wyniki okresowych pomiarów poziomów substancji lub energii w środowisku przekazuje się w terminie 21 dni od daty wykonania pomiarów.

$\S 7$. Rozporządzenie weszło $\mathrm{w}$ życie $\mathrm{z}$ dniem 1 stycznia $2004 \mathrm{r}$.

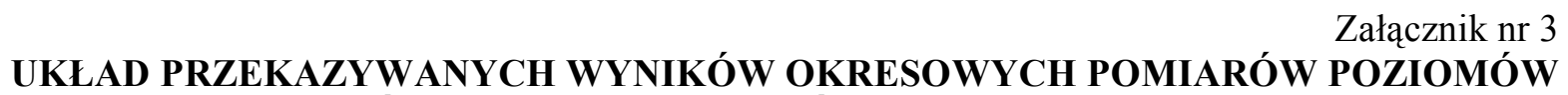 HAŁASU W ŚRODOWISKU DLA DRÓG, LINII KOLEJOWYCH I LINII TRAMWAJOWYCH}

Nazwa obiektu

Data wykonania pomiaru

Lokalizacja punktu pomiarowego. 
Układ współrzędnych płaskich prostokatnych „1992":

Długość geograficzna

Szerokość geograficzna

Względna wysokość punktu pomiarowego [m].

Opis i charakterystyka źródel hałasu (w tym natężenia ruchu, parametry ruchu, liczby pojazdów)

\section{Szkic sytuacyjny:}

Szkic sytuacyjno-wysokościowy w skali 1: 500 lub 1: 1000, z oznaczeniem kierunku wiatru, położeniem terenów chronionych przed hałasem i z opisem dopuszczalnych poziomów hałasu

\footnotetext{
Metoda badań:

Metoda pośrednia, to jest metoda pomiarów sygnałów elementarnych.

Metoda bezpośrednich pomiarów hałasu z wykorzystaniem próbkowania

Metoda bezpośrednia ciągłych pomiarów w ograniczonym czasie.

Metoda obliczeniowa oparta o modele rozprzestrzeniania się dźwięku w środowisku...

Warunki atmosferyczne:

Zmierzone na wysokości.
}

\begin{tabular}{|l|l|l|l|}
\hline \multicolumn{1}{|c|}{ Wartości mierzone } & $\begin{array}{c}\text { Wartości maksy- } \\
\text { malne }\end{array}$ & $\begin{array}{c}\text { Wartości mini- } \\
\text { malne }\end{array}$ & $\begin{array}{c}\text { Wartości śred- } \\
\text { nie }\end{array}$ \\
\hline prędkość $\mathrm{i}$ kierunek wiatru: $\mathrm{m} / \mathrm{sek} /{ }^{\circ}$ & & & \\
\hline temperatura otoczenia: ${ }^{\circ} \mathrm{C}$ & & & \\
\hline wilgotność względna $\%$ & & & \\
\hline ciśnienie atmosferyczne $(\mathrm{hPa})$ & & & \\
\hline stan pogody w okresie wykonania pomiaru & \multicolumn{3}{|l|}{} \\
\hline inne spostrzeżenia & \multicolumn{2}{|l|}{} \\
\hline
\end{tabular}

Aparatura pomiarowa:

typ ............, z mikrofonem typu

świadectwo uwierzytelnienia $\mathrm{nr}$

Urzędu Miar w Warszawie, ważne do dnia

wydane dnia ..... przez Prezesa Głównego

Parametry pomiaru: stała czasowa:

korekcja:

Warunki pozaakustyczne: odpowiednio dla źródła emisji hałasu (natężenie ruchu pojazdów z uwzględnieniem udziału pojazdów ciężkich, liczby przejeżdżających pociągów, tramwajów)

WYNIKI POMIARÓW

Metoda pośrednia - metoda pomiarów sygnałów elementarnych

\begin{tabular}{|c|c|c|c|}
\hline Lp. & $\begin{array}{c}\text { Kategoria sygnału } \\
\text { elementarnego }\end{array}$ & Numer pomiaru & $\begin{array}{c}\text { Zmierzone wartości ekspozycyjnego } \\
\text { poziomu dźwięku A, [dB] }\end{array}$ \\
\hline & & & \\
\hline
\end{tabular}

Data przeprowadzenia pomiarów: od godz (data) do godz. (data)

Określenie średnich wartości poziomów ekspozycyjnych dla każdej kategorii sygnału elementarnego wraz z odchyleniem standardowym

\section{Określenie równoważnego poziomu hałasu wraz z niepewnością wyniku}

(opis sposobu określenia równoważnego poziomu dźwięku oraz niepewności pomiaru, tabelaryczne zestawienie uzyskanych wartości) 
Metoda bezpośrednich pomiarów hałasu z wykorzystaniem próbkowania

\begin{tabular}{|l|c|c|c|c|c|}
\hline \multirow{2}{*}{ Lp. } & \multirow{2}{*}{$\begin{array}{c}\text { Numer } \\
\text { pomiaru }\end{array}$} & \multirow{2}{*}{$\begin{array}{c}\text { Czas } \\
\text { pomiaru t }[\mathbf{s}]\end{array}$} & $\begin{array}{c}\text { Poziom równoważny } \\
\text { zmierzony w czasie t [dB] }\end{array}$ & $\begin{array}{c}\text { Poziom } \\
\text { maksymalny [dB] }\end{array}$ & $\begin{array}{c}\text { Poziom minimal- } \\
\text { ny [dB] }\end{array}$ \\
\hline & & & & & \\
\hline & & & & & \\
\hline
\end{tabular}

Data przeprowadzenia pomiarów: od godz. do godz. (data) (data)

Określenie równoważnego poziomu hałasu wraz z niepewnością wyniku

(opis sposobu określenia równoważnego poziomu dźwięku oraz niepewności pomiaru, tabelaryczne zestawienie uzyskanych wartości)

Metoda bezpośrednia ciągłych pomiarów w ograniczonym czasie

\begin{tabular}{|c|c|c|}
\hline Lp. & Pora pomiaru & $\begin{array}{c}\text { Wartość równoważnego } \\
\text { poziomu dźwięku (zmierzona), [dB] }\end{array}$ \\
\hline & & \\
\hline & & \\
\hline
\end{tabular}

Data przeprowadzenia pomiarów: od godz. do $\operatorname{godz}$ (data) (data)

Określenie równoważnego poziomu hałasu wraz z niepewnością wyniku

(opis sposobu określenia równoważnego poziomu dźwięku oraz niepewności pomiaru, tabelaryczne zestawienie uzyskanych wartości)

Metoda obliczeniowa oparta o modele rozprzestrzeniania się dźwięku w środowisku

Zastosowany model obliczeniowy (charakterystyka):

Dane wejściowe do modelu:

Wyniki pomiarów danych wejściowych do modelu, o ile takie były wykonywane,

Dane wejściowe do modelu pozyskane w inny sposób niż za pomocą pomiarów (źródło danych, wiarygodność danych)

\section{Określenie równoważnego poziomu hałasu}

(opis sposobu określenia równoważnego poziomu dźwięku oraz niepewności pomiaru, tabelaryczne zestawienie uzyskanych wartości)

Graficzne przedstawienie zasięgu hałasu (o ile takie oceny wykonano) Szkic sytuacyjno-wysokościowy w skali 1: 500 lub 1: 1000

Inne, nie wymienione wyżej, dane rejestrowane w czasie badań, wynikające z referencyjnej metodyki pomiarów

Okres przeprowadzenia pomiarów: od $\operatorname{god} z$. do godz. ..........

Wykonujący pomiar: (data) (data i podpis) Zarządzający: (data i podpis) 


\section{Rozporządzenie Ministra Środowiska $\mathrm{z}$ dnia 14.10.2002r. [5]}

Zgodnie z Rozporządzeniem Ministra Środowiska w sprawie szczegółowych wymagań, jakim powinien odpowiadać program ochrony środowiska przed hałasem. Kolejność realizacji zadań programu na terenach mieszkaniowych następuje z uwzględnieniem wskaźnika charakteryzującego wielkość przekroczenia dopuszczalnego poziomu hałasu i liczbę mieszkańców na terenie, ustalonego w sposób następujący: „Kolejność realizacji zadań programu na terenach mieszkaniowych (...) ustala się, zaczynając od terenów o najwyższej wartości wskaźnika $M$ do terenów o wartości wskaźnika M najniższej. Punktem wyjścia do ustalenia kolejności realizacji inwestycji jest tzw. współczynnik M, obliczany wg następującej zależności:

$$
M=0,1 m\left(10^{0,1 D L}-1\right)
$$

gdzie:

M - wartość wskaźnika,

DL - wielkość przekroczenia dopuszczalnego poziomu hałasu $\mathrm{dB}$,

M - liczba mieszkańców na terenie o przekroczonym poziomie dopuszczalnym

W programie określa się i ocenia następujące zagadnienia:

1) powstającą emisję hałasu w związku z eksploatacją:

d) dróg, linii kolejowych, linii tramwajowych, lotnisk oraz portów;

2) powstający hałas $w$ środowisku $w$ związku $z$ eksploatacją źródeł hałasu, o których mowa w pkt 1, przed i po realizacji zadań programu, z uwzględnieniem liczby mieszkańców na terenie objętym programem;

3) efektywności ekologicznej i ekonomicznej zadań programu we wzajemnym ich powiązaniu.

\section{Określanie niepewności pomiarów akustycz- nych [18]}

W pomiarach poziomu hałasu od linii tramwajowej lub kolejowej mierzymy ekspozycyjne poziomy dźwięku $L_{A E}$ dla pojedynczych zdarzeń akustycznych (przejazdów), grupowanych w odpowiednie klasy.

Uzyskujemy w ten sposób zbiory wartości $L_{A E i}$ dla każdej z klas z osobna.

Jednak z uwagi, że są to poziomy dźwięku wyrażane w decybelach - nie mają one cechy addytywności (nie dodają się arytmetycznie) - zatem nie można bezpośrednio do nich stosować znanych wzorów statystycznych, zawartych w podręcznikach.

W celu prawidłowego wykonania rachunków statystycznych należy ,odlogarytmować” poziomy, czyli wyrazić zmierzone zdarzenia jako ekspozycje względne określone wzorem:

$$
E_{E i}=10^{0,1 \cdot L_{A E i}}
$$

I dopiero na tak uzyskanym zbiorze wartości ekspozycji względnych (mających cechę addytywności) możemy wykonywać rachunki stosując znane wzory statystyczne.

Określamy zatem przedział niepewności o zadanym poziomie ufności (zazwyczaj 95\%) dla wartości ekspozycji względnych. Konsekwencja tego faktu jest - po ponownym przeliczeniu na poziomy dźwięku w celu wyrażenia wyniku końcowego w decybelach - asymetryczne granice przedziałów niepewności wyrażanych w decybelach względem wartości średniego poziomu ekspozycyjnego.

Szczegółowe sposoby obliczania niepewności typu A (statystyka pomiarowa) oraz typu B (niedokładności związane z aparaturą, czynnikami zewnętrznymi czy modelowaniem zdarzenia) w celu określenia niepewności rozszerzonej uzyskanego wyniku badania (zbioru wyników pomiarów) są przedstawione w artykułach na stronie internetowej www.ntlmk.com w zakładce „E-biblioteka”.

\section{Literatura}

[1] Dyrektywa 2002/49/WE z dnia 25.06.2002r. „,Ocena i kontrola poziomu hałasu w środowisku",

[2] PN-91/K11000 „, Tabor kolejowy. Hałas”

[3] Prawo Ochrony Środowiska - Dz.U. Nr.62 poz. 627 z dnia 27.04.2001r.

[4] Dz. U. Nr.8 poz.81 2002r. Rozporzqdzenie Ministra Środowiska z dnia 09.01.2002r. w sprawie wartości progowych poziomów hałasu.

[5] Dz. U. Nr.179 poz.1498 Rozporzqdzenie Ministra Środowiska z dnia 14.10.2002r. w sprawie szczegótowych wymagań, jakim powinien odpowiadać program ochrony środowiska przed hałasem.

[6] Dz. U. Nr.18 poz.164 Rozporzqdzenie Ministra Środowiska z dnia 17.01.2003r. w sprawie rodzajów wyników pomiarów prowadzonych $w$ zwiazku $z$ eksploatacja dróg, linii kolejowych, linii tramwajowych, lotnisk oraz portów, które powinny być przekazywane właściwym organom ochrony środowiska, oraz terminów i sposobów ich prezentacji.

[7] Dz. U. Nr.1 poz. 8 2007r. Rozporzqdzenie Ministra Środowiska z dnia 14.12.2006r. w sprawie dróg, linii kolejowych i lotnisk, których eksploatacja moze powodować negatywne oddziatywanie akustyczne na znacznych obszarach, dla których jest wymagane sporzadzanie map akustycznych, oraz sposobów określania granic terenów objętych tymi mapami.

[8] M.P. Nr.65 poz.732 Obwieszczenie Ministra Środowiska z dnia 18.09.2007r. w sprawie wysokości stawek kar za przekroczenie warunków wprowadzenia ścieków do wód lub do ziemi oraz przekroczenie dopuszczalnego poziomu hałasu, na rok 2008 . 
[9] Dz. U. Nr.120 poz.826 Rozporzqdzenie Ministra rodowiska $z$ dnia 14.06.2007r. w sprawie dopuszczalnych poziomów hałasu $w$ środowisku.

[10] Dz. U. Nr.187 poz.1340 Rozporzqdzenie Ministra Środowiska z dnia 1.10.2007r. w sprawie szczegółowego zakresu danych ujętych na mapach akustycznych oraz ich uktadu i sposobu prezentacji.

[11] Dz. U. Nr.192 poz. 1392 Rozporzqdzenie Ministra Środowiska z dnia 2.10.2007r. w sprawie wymagań $w$ zakresie prowadzenia pomiarów poziomów $w$ środowisku substancji lub energii przez zarzqdzajacego droga, liniq kolejowa, liniq tramwajowa, lotniskiem, portem.

[12] Dz. U. Nr.210 poz.1535 Rozporzadzenie Ministra Środowiska z dnia 7.11.2007r. zmieniajace rozporzqdzenie $w$ sprawie ustalania wartości hałasu $L(D W N)$
Dz. U. Nr.106 poz.729 2007r.

PN ISO 9613-2 „Akustyka. Tłumienie dźwięku podczas propagacji $w$ przestrzeni otwartej. Obliczanie pochtaniania dźwięku przez atmosferę/Ogólna metoda obliczania"

[15] PN ISO 1996-1/2/3 „Opis $i$ pomiary hatasu środowiskowego. Podstawowe wielkości $i$ procedury"

[16] www.portaldrogowy.pl

[17] Dębicka-Fobie G., Jankowska M.; ,Zagadnienia $i$ wytyczne dotyczace Ochrony Środowiska w UE”, Zwiazek Rzemiosła Polskiego 2004r.

[18] Strona internetowa firmy NTL-M.Kirpluk: www.ntlmk.com, zakładka ,E-biblioteka” 